\title{
Adaptive Behavior and Family Burden in Patau Syndrome: Case
}

\section{Report}

\begin{abstract}
Keywords: Adaptation psychological; Congenital abnormalities: Family relations

Abstract

The Patau syndrome is a rare autosomal trisomy, characterized by the fetal malformations involving the central nervous system, among others. The phenotype of Patau syndrome causes impact on families by the vulnerability and involvement in the child's life by changing the lifestyle, emotional balance and interpersonal relationships. This study aimed to investigate the literature, empirical studies of the syndrome, related to the development, and describe the clinical of a child with that diagnosis, female, with 04 years and 11 months, relating to maternal level of overload. The evaluation of the development was instrumented by the Vineland Adaptive Behavior Scale and overload by Bourden Interview Scale. The results showed damage in all areas of development, with relevance for communication and autonomy. The absence of high overload was suggestive of that family support may have mitigated the impact of care and reflected positively on the caregiver quality of life.
\end{abstract}

\section{Introduction}

The Patau syndrome, also known as Trisomy 13, is a genetic disorder which is characterized by multiple fetal malformations, involving the central nervous, cardiovascular and urogenital systems, among others [1-6]. It refers to the disjunction of the chromosomes during the anaphase 1 of meiosis, resulting in 24 gametes chromatids. It is the third more frequent autosomal trisomy, although considered a rare syndrome $[7,8]$.

The major detected malformations of the central nervous system were holoprosencephaly, cerebellar changes, corpus callosum agenesis and hydrocephalus. Nonetheless, there are other factors that indicate this syndrome $[1,9,10]$. The clinical findings show that, from 50 to $80 \%$ can show apnea and tremors, microphthalmia, cleft lip and palate, polydactyly, congenital heart disease, epicanthic fold, deafness, micrognathia, excess skin on the neck or short neck, capillary hemangiomas, long and hyperconvex fingernails, retroflexible thumbs, flexion deformity of the fingers, single palmar crease, halucal standard tibial strap, prominent calcaneus, hypotonia, plus many other findings also described $[5,9,10]$. Only $5 \%$ of the cases survive more than three years [11], and on literature, there are few described cases of children that survive beyond that age [4,12-16].

The Patau syndrome phenotype affects the families. The birth of a child with chromosomal abnormality is a critical and remarkable event in the family routine because of the vulnerability and involvement of diseases and chronic conditions that compromise the child's life by changing the lifestyle, emotional balance and interpersonal relationships [17]. Dealing with the low life expectancy is a stressing event for the family, which has a big interest regarding the prognosis,
Journal of

Neurology and Psychology

\section{Maria de Lourdes Merighi Tabaquim ${ }^{1^{\star}}$, Belisa Brisola Brito Prado ${ }^{2}$, Sylvia Maria Ciasca ${ }^{3}$, Maria Valeriana Leme de Moura-Ribeiro ${ }^{4}$ and Dionísia Aparecida Cusin Lamônica ${ }^{5}$}

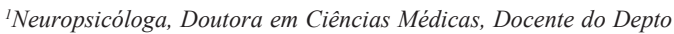
de Fonoaudiologia da Faculdade de Odontologia da Universidade de São Paulo (FOB-USP) e da Pós graduação do Hospital de Reabilitação em Anomalias Craniofaciais (HRAC-USP), Endereço: R. Bandeirantes, $n^{\circ}$ 9-60 Apto 61 Centro Cep 17015-012 Bauru, São Paulo, Brazil

${ }^{2}$ Psicóloga, Especialização em Neuropsicologia aplicada à Neurologia Infantil, Centro de Reabilitação Piracicaba, São Paulo, Brazil.

${ }^{3}$ Neuropsicóloga, Livre Docente em Ciências Médicas, Docente do Depto de Neurologia da Faculdade de Ciências Médicas da Universidade de Campinas (FCM/Unicamp), São Paulo, Brazil.

${ }^{4}$ Neurologista Infantil, Titular em Neurologia Infantil da Universidade Estadual de Campinas, São Paulo, Brazil.

${ }^{5}$ Fonoaudióloga, Doutora em Ciências da Comunicação, Docente do Depto e do Programa de Pós graduação em Fonoaudiologia da Faculdade de Odontologia da Universidade de São Paulo, São Paulo, Brazil.

\section{*Address for Correspondence}

Maria de Lourdes Merighi Tabaquim, Neuropsicóloga, Doutora em Ciências Médicas, Docente do Depto de Fonoaudiologia da Faculdade de Odontologia da Universidade de São Paulo (FOB-USP) e da Pós graduação do Hospital de Reabilitação em Anomalias Craniofaciais (HRAC-USP), Endereço: R. Bandeirantes, n 9-60 Apto 61 Centro Cep 17015-012 Bauru, São Paulo, Brazil, Tel: 55-14-32358232; E-mail: malu.tabaquim@usp.br

\author{
Submission: 26 February, 2016 \\ Accepted: 14 March, 2016 \\ Published: 19 March, 2016 \\ Copyright: $\odot 2016$ Tabaquim MdLM, et al. This is an open access article \\ distributed under the Creative Commons Attribution License, which \\ permits unrestricted use, distribution, and reproduction in any medium, \\ provided the original work is properly cited. \\ Reviewed \& Approved by: Dr. Roberto Maniglio, Clinical \\ Psychology, University of Salento, Italy
}

development advances and the life expectancy of the child.

Searching the literature about the Patau syndrome, 151 studies in PUBMED and 6 in SCIELO, described in the last 10 years, were found. Using the key words "Patau syndrome and cognition", one study was found [18]; using the key words "language", "speech", "motor", "child development", no studies were found. Using the key words "Patau syndrome and family", 12 articles in English were found. Of these, only 5 relate the experiences of parents dealing with the disorder [1923], two of these are accounts of personal experiences [19,22], and the rest relate ethical aspects, prenatal diagnosis and family findings.

The term "caregiver burden" has been used to refer to physical, psychological or emotional problems that generally are experienced by the relatives of people that have dependencies, caused by deficiencies, disorders and limitations [24,25]. Understanding the "caregiver burden" refers to objective and subjective concepts [26,27]. The objective burden is determined by the frequency of assistance and supervision of the caregiver in the daily care of the dependent, whom concrete demands involve the excess of tasks, supervision 
of behaviors, financial difficulties and disturbances in their routine and social life. The subjective burden is determined by the level of discomfort felt by the caregiver when exerting his role in care and concerns with the dependent, being related to the universe of feelings concerning present and future, dealing with problematic situations, feelings of loss, guilt, shame, powerlessness and helplessness.

In the traditional family setting, the woman still has a predominant role taking care of the house and children [28]. For Pimenta et al. among the possible factors that influence the male parent involvement, can be highlighted the motivation, which would be the desire of involvement (based on the involvement with their own parents); habilities and availability (needed in the care of children); and support (approval of that involvement by the family and social group) [17].

On the above, this study aims to verify the adaptive behavior and family burden of a Patau syndrome case in a 4 years and 11 months old girl, with literature review on topic.

\section{Case Report}

This clinical study was the opinion embodied approved by the Ethics Committee of the Faculty of Medical Sciences of Unicamp under number 558524 of 03/20/2014. With the ethical procedures adopted, participated in the study a female child, aged 04 years and 11 months, diagnosed with Patau's syndrome, and her mother as caregiver.

The mother related unplanned pregnancy at the age of 18 . She held prenatal. Presented high blood pressure at the end of pregnancy. The child was born at term (40 weeks gestation), cesarean birth, weighing 2,490 kg and $44 \mathrm{~cm}$ of height. The Apgar evaluation indicated 9 and 10 at minutes 1 and 5, respectively, thus indicating satisfactory birth conditions. Presented physiologic jaundice, around the third day after birth, due to increased load and decreased excretion of bilirubin, ceasing at the end of day 7 .

The medical evaluation found polydactyly, presenting six fingers on each hand, and six toes on the left foot, and also short lingual frenulum. Had surgical intervention with three days of life, remaining hospitalized for five more days, due to clinical complications (changes in suction functions and respiration). At the time of hospital discharge, the family was informed of the syndrome traces and the need for genetic evaluation. The genetic evaluation was performed by examining the karyotype, at one month and ten days of life. The result indicated the presence of $46, \mathrm{XX}, \operatorname{der}(17) \mathrm{t}(13,17)$ (q14; q25), in all analyzed cells; derivative 17 chromosome, a result of translocation of chromosome 13 as part, which means a diagnosis of trissomy part of chromosome 13, compatible with Patau syndrome.

The child presented the following characteristics: apnea and tremors, microcephaly, microphthalmia, cleft lip and palate, polydactyly, congenital heart disease, epicanthic fold, presumptive deafness, micrognathia, excess skin on the neck or short neck, capillary hemangiomas, long and hyperconvex nails, retroflexible thumbs, flexion deformity of the fingers, single palmar crease, halucal standard tibial strap, prominent calcaneus, recurring seizures in focal epilepsy, holoprosencephaly, cerebellar changes and agenesis of the corpus callosum.
The information of diagnosis was transmitted by the medical staff objectively, indicating survival reduction. The mother informed that feelings of uncertainty and fear were her initial reactions to the diagnosis. The father became not interested and remained absent from the child's education throughout the development.

The child had development delay. Smiled for the first time at 4 months of life, acquired cervical balance at 5 months, rolled at 8 months, sat without support at 1 year and 8 months, crawled at 2 years and 2 months, stood up at 2 years and 6 months and walked at 3 years. Was not breastfed (due to suction difficulties, as justified by the mother), and used the baby bottle until 3 years old.

Up to the current age, she had not acquired toilet training. Sleep changes was related, with agitation, gnashing of teeth at night (and day), and unsystematic seizures. Anxiety was evident, with running without direction and agitated movements, behaviors of self-harm, with attempts to pluck hair. Was seen, also, high level of social and practical dependency, interaction difficulties and tendency to isolation. Presence of stereotyped movements, like the flap, hitting the hand on head, putting the ear against the wall as if wanting to hear something. Visual contact, attention and concentration was always characterized as poor. Does not show fear in face of unknown and dangerous situations.

Frequents daycare at afternoon, was a need since first year of life. Presents difficulties in connecting with peers and following class activities. Weekly does speech and language and occupational therapies. At morning, is taken care by maternal grandmother, and at night is taken care by the mother, who interacts with daughter at dinner time, at bath time and before going to sleep, including both sleeping on the same bed. At the time of evaluation, was making use of medications of barbiturate drug type with anticonvulsant properties and atypical antipsychotics.

On Observation of Communicative Behavior, it was verified agitation/hyperactivity, limited oral communication (babbling), however, presented interactive behavior, although with restrictive visual contact and reduced attention time. Responded at hearing stimulations on a unsystematic way, recognized sounds, smiled in response to the adult, understanding simple orders in a concrete and immediate context, like "come", "give" and "no". Absence of oral communication. Presented interest on people and toys, however, with poor handling. Presence of imitation behaviors, in movements like clapping hands and saying "bye".

The Vineland Adaptive Behavior Scales [29] was used to verify the adaptive performance. The scale is divided into four domains, subdivided into 11 subdomains:Communication - Receptive, Expressive and Writing; Autonomy - Individual, Domestic and Community; Socialization - Interpersonal Relationships, Leisure and Social Rules; Motricity - Fine and Coarse. The scale was managed by a structured interview with the mother, and analyzed according to norms of instrument for obtaining the index of Adaptive Behavior.

The Table 1 presents the results obtained on the Adaptive Behavior Scale.

To evaluate the overburden of the caregiver, the Bourden Interview Scale - BI [30] was used, translated and validated to 
Table 1: Adaptative Behavior Scale: expected/obtained and percentage of skill acquisition.

\begin{tabular}{|c|c|c|c|c|}
\hline \multicolumn{2}{|c|}{ Behavior adaptative } & Expected & Obtained & $\begin{array}{c}\text { Aquisition } \\
(\%)\end{array}$ \\
\hline \multirow{2}{*}{ Communication } & Receptive & 24 & 4 & 16,6 \\
\cline { 2 - 5 } & Expressive & 42 & 2 & 4,7 \\
\hline \multirow{3}{*}{ Autonomy } & Personal & 50 & 9 & 18 \\
\cline { 2 - 5 } & Doméstic & 6 & 1 & 16,6 \\
\cline { 2 - 5 } & Comunity & 10 & 0 & 0 \\
\hline \multirow{3}{*}{ Socialization } & Interpersonal & 40 & 6 & 15 \\
\cline { 2 - 5 } & $\begin{array}{c}\text { G a m e s } \\
\text { Recreation }\end{array}$ & 24 & 5 & 21 \\
\cline { 2 - 5 } & Social Rules & 10 & 0 & 0 \\
\hline \multirow{2}{*}{ Motricity } & Global & 34 & 30 & 88 \\
\cline { 2 - 5 } & Slim & 24 & 14 & 58 \\
\hline
\end{tabular}

Table 2: Percentage of answers related to $\mathrm{BI}$.

\begin{tabular}{|c|c|c|}
\hline Scale BI & \multicolumn{1}{|c|}{ Description } & $\%$ \\
\hline Never & $\begin{array}{l}\text { Shame, stress, irritation, interference, damage to } \\
\text { health, overload, lack of financial resources, care for } \\
\text { disability. }\end{array}$ & 54,5 \\
\hline Sometimes & $\begin{array}{l}\text { She asks more help than she needs, be afraid of the } \\
\text { future, of losing control over life, questions of what } \\
\text { to do for the child, think you should be doing more. }\end{array}$ & 22,7 \\
\hline Often & No time for yourself & 4,5 \\
\hline Rarely & Stress overload, lack of privacy, lack of social life & $13,6 \%$ \\
\hline Always & Feelings of full dependence. & 4,5 \\
\hline
\end{tabular}

Brazilian population. It contains 22 questions, englobing areas such as health, social and personal life, financial situation, well-being, emotional behavior and interpersonal relationships. The answer score is based on Likert scale, that specifies 5 levels of agreements with the statement ( 0 to 4 ). The final score of the $\mathrm{BI}$ is obtained by the sum total of answers (which vary from 0 to 88 ) and indicates that the higher the final score, the higher the overburden of caregiver.

Table 2 presents the description and percentage obtained by the burden scale, along with the caregiver of the study.

The results indicated to 20 points obtained, which represented an absence of overburden $(\leq 21)$. The highest percentage occurred, on the scale, with the alternative "never", with $54,5 \%$ of answers given by caregiver, whom aspects were related to the overburden factor.

\section{Discussion}

Motricity involves all and any gesture that surrounds the global development of the child, concerning body movement, expressing knowledge, ideas, feelings and emotions. Fonseca highlights the importance of motricity in human development, emphasizing that affective, cognitive and motor aspects must be seen on an inseparable form in the process of construction of person [30]. In human development, it is important that the motor on Vineland Scale, the child presented, regarding adaptive behavior of global motricity, a result near expected. This can be understood by the fact that $(\mathrm{M})$ does not have motor limitations, and allied to this, was stimulated in rehabilitation since was a baby. The environment, full of stimulations and opportunities of experience motor activities may have contributed for the development observed in this study. The lag observed in motor refinement activities, such as catching a ball with hands, dressing and undressing, building block towers, among other activities expected of being done by a child of that age group, can be comprehended by the inefficiency of perceptual and motor integrative actions, suggestive of corpus callosum dysfunction, typical of the syndrome. According to Bee and Boyd $[31,32]$, perception and movement domination, although being in the first years of life, the higher level of development occur in later stages.

In the development of the child, the receptive language predates the expressive one, and the explosion of appointment is not a regular, gradual process. Hypotonic individuals with specific changes, like the syndromic [33], can present more difficulty on joints and phonemic acquisitions, in functionality and mobility of the tongue and lips, compromising the expressiveness of communication [34]. In this study, demonstrated inefficiency of communication by speech.

Many mother and child relationships are based on maternal overprotection attitudes, and this trend increases when the child has some deficiency [35]. This overprotection can be rooted on abandonment and uncertainties experiences suffered. Frequently, there are accounts of mothers who find themselves alone, fathers that abandoned their women, and then fully assume the child care (medically, therapeutically, educationally), besides assuming financially the expenses of the family. In the case of $(\mathrm{M})$, the father was absent, and the mother, main caregiver, found support in the maternal grandmother, elected as a "secondary" caregiver, this fact which can be constituted as one of the factors for the absence of an overburden of the caregiver. On the other hand, the caregiver showed attitudes of overprotection, as evident when returning from work, with compensation of controlling actions, such as sleeping on the same bed, thus creating favorable situations to a lack of self-esteem for the child.

The birth effects, for the family, on a child that has deficiency, can vary and are related to countless factors, among them the way how the story occurred and how the diagnosis happened. The account of caregiver about the story of the child indicated performance of two ultrasounds during prenatal. The importance of the ultrasound is "to detect or discard neural tube defects or other physical abnormalities" [32]. However, what cause estrangement was the fact of the ultrasounds results had not shown or informed the mother of (M) about the presence of six fingers on each hand and six toes on left foot (polydactyly). The information given to mother was that the test result was within the normal range. Had that anomaly being found during pregnancy could have minimize the impact of the news about the child's birth with malformation, and making possible the preparation of idealized loss, including the adequate assistance of Psychology professionals.

The result of evaluation with absence of the overburden of the mother showed a favorable factor regarding quality of life of the caregiver, because according to Manoel and collaborators [25], the term "caregiver burden" is used to refer physical, psychological or emotional problems, which are generally experienced by the relatives of people who present dependencies, originated by deficiencies, disorders and limitations. In this study, the Bourden Interview Scale evaluated the impact of overburden in family life aspects, in other words, of the caregiver, regarding health, social and personal 
Citation: Tabaquim MdLM, Prado BBB, Ciasca SM, Moura-Ribeiro MVLd, Lamônica DAC. Adaptive Behavior and Family Burden in Patau Syndrome: Case Report. J Neurol Psychol. 2016; 4(1): 5.

ISSN: 2332-3469

life, financial situation, emotional well-being and interpersonal relationships.

The research of Pimenta, et al. related to caregiver burden, showed that the role of caregiver generally belongs to the feminine gender, and that responsibility is assumed in a spontaneous form or not among others [17]. In this study, the father constituted in an absent figure by abandonment, characterized by the lack of involvement in interaction and availability with the child, as well as responsibility about treatments and life structure.

In this case, the caregiver of $(\mathrm{M})$ and main responsible was the mother, who exerted a leadership role in terms of decision making, daily life activities organization and other orientation for the "secondary" caregiver, in this case, the maternal grandmother of (M). That join, as a network support, was necessary to the financial organization of the family, but that reflected positively in the absence of overburden. This objective overburden [26,27], that could represent great impact, showed to be ameliorated by the fact of sharing responsibility both material and emotional, having support from other families, which helped the coexistence of the main caregiver to provide $(\mathrm{M})$ being more socially included, attending the activities at the daycare, doing public tours (shopping, parks ...), providing to (M) interaction with the outside world.

The constituted family network support seemed to favor the formation of bonds and structuring the child's life, expanding their possibilities, starting from the self-esteem arising from affection. Thus, the context must be valued regarding the development and socialization, observed in the child.

Nonetheless, the subjective overburden [27], determined by the uncomfortable felt by the caregiver in supervision of problematic and dependable behavior, manifested in the protocol adopted in the study, indicated a representative percentage about concerns regarding survival and future conditions of the child. Despite the importance attributed to the family, besides the great number of works taking it as an object of study, the knowledge about their dynamic of relationships is limited, mainly when one or more of the members have some kind of deficiency [24]. Literature has contemplated many more studies about a person with deficiency than the ones which focus on dynamics of family relationships, exactly because of its complexity and variability, making impossible universal generalizations about nature and its influences.

showing attitudes that demonstrated ambivalence of feelings in taking care of the child, such as controlling and overburden, it was possible to identify in the caregiver's speech expressions of comprehension about limitations and potentiality, demonstrating emotional balance to deal with the complexity of the child's condition and the acknowledgement of the multi-professional interventional work (doctor, psychologist, physiotherapist, occupational therapist, speech therapist and teachers), from the little advances in rehabilitation, to the weaknesses inherent in clinical condition of $(M)$.

\section{References}

1. Iliopoulos D, Sekerli E, Vassiliou G, Sidiropoulou V, Topalidis A, et al. (2006) Patau syndrome with a long survival (146 months): a clinical report and review of literature. Am J Med Genet A 140: 92-93.

2. Nanjiani A, Hossain A, Mahgoub N (2007) Patau syndrome. J Neuropsychiatry Clin Neurosci Spring 19: 201-202.
3. Plaiasu V, Ochiana D, Motei G, Anca I, Georgescu A (2010) Clinical relevance of cytogenetics to pediatric practice. Postnatal findings of Patau syndrome Review of 5 cases. Maedica (Buchar) 5: 178-185.

4. Bruns D (2011) Birth history, physical characteristics, and medical conditions in long-term survivors with full trisomy 13. Am J Med Genet A 155A: 26342640.

5. Pimenta RD, Rodrigues L, Greguol M (2010) Avaliação da Qualidade de Vida e Sobrecarga de Cuidadores de Pessoas com Deficiência Intelectual. Rev Bras de Ciências da Saúde14: 69-76.

6. Bazán-Ruiz S, Bendezú-Quisp G, Huiza L (2014) Syndrome de Patau. Rev Med Hered 25: 52-52.

7. Caba L, Rusu C, Butnariu L, Panzaru M, Braha E, et al. (2013) Phenotypic variability in Patau syndrome. Rev Med Chir Soc Med Nat lasi 117: 321-327.

8. Wu J, Springett A, Morris JK (2013) Survival of trisomy 18 (Edwards syndrome) and trisomy 13 (Patau Syndrome) in England and Wales: 20042011. Am J Med Genet A 161A: 2512-2518.

9. Rosa RF, Rosa RC, Flores JA, Chazan DT, Dietrich C, et al. (2011) Trisomy 13 (Patau syndrome) and craniosynostosis. Am J Med Genet A 155A: 20182020.

10. Tsukada K, Imataka G, Suzumura H, Arisaka O (2012) Better prognosis in newborns with trisomy 13 who received intensive treatments: a retrospective study of 16 patients. Cell Biochem Biophys 63: 191-198.

11. Boghossian NS, Hansen NI, Bell EF, Stoll BJ, Murray JC, et al. (2014) Mortality and morbidity of VLBW infants with trisomy 13 or trisomy 18 Pediatrics 133: 226-235.

12. Santos SL, Álvarez Herrero C, Sánchez L, Sierra-Santos E (2001) Patau's syndrome, a survival that gets over the prognosis. Medifam 1: 70-74

13. Duarte AC, Menezes Al, Devens ES, Roth JM, Garcias GL, et al. (2004) Patau syndrome with a long survival. A case report. Genet Mol Res 3: 288292.

14. Fogu G, Maserati E, Cambosu F, Moro MA, Poddie F, et al. (2008) Patau syndrome with long survival in a case of unusual mosaic trisomy 13. Eur J Med Genet 51: 303-314.

15. Tunca Y, Kadandale JS, Pivnick EK (2001) Long-term survival in Patau syndrome. Clin Dysmorphol 10: 149-150.

16. Jaru-Ampornpan P, Kuchtey J, Dev VG, Kuchtey R (2010) Primary congenital glaucoma associated with Patau syndrome with long survival. J Pediatr Ophthalmol Strabismus 47 Online: e1-e4.

17. Pimenta RD, Rodrigues L, Greguol M (2010) Avaliação da qualidade de vida e sobrecarga de cuidadores de pessoas com deficiência intelectual. Rev Bras de Ciências da Saúde 14: 69-76.

18. Hutaff-Lee C, Cordeiro L, Tartaglia N (2013) Cognitive and medical features of chromosomal aneuploidy. Handb Clin Neurol 111: 273-279.

19. Farlow B (2011) Choosing the road less traveled. Curr Probl Pediatr Adolesc Health Care 41: 115-116.

20. Carey JC (2012) Perspectives on the care and management of infants with trisomy 18 and trisomy 13: striving for balance. Curr Opin Pediatr 24: 672 678.

21. Janvier A, Farlow B, Wilfond BS (2012) The experience of families with children with trisomy 13 and 18 in social networks. Pediatrics 130: 293-298.

22. Whitehall JS (2013) The power of 13. Med J Aust 199: 798-799.

23. Guon J, Wilfond BS, Farlow B, Brazg T, Janvier A (2014) Our children are not a diagnosis: the experience of parents who continue their pregnancy after a prenatal diagnosis of trisomy 13 or 18. Am J Med Genet A 164: 308-318.

24. Chacon MC (2011) Aspectos relacionais, familiars e sociais da relação paifilho com deficiência física. Rev Bras Educ Espec 17: 124-132.

25. Manoel MF, Teston EF, Waidman MA, Decesaro MN, Marcon SS (2013) As relações familiares e o nível de sobrecarga do cuidador familiar. Esc Anna Nery 17. 
Citation: Tabaquim MdLM, Prado BBB, Ciasca SM, Moura-Ribeiro MVLd, Lamônica DAC. Adaptive Behavior and Family Burden in Patau Syndrome: Case Report. J Neurol Psychol. 2016; 4(1): 5.

26. Bandeira M, Calzavara MG, Varella AA (2005) Escala de Sobrecarga dos Familiares de Pacientes Psiquiátricos adaptação transcultural para o Brasil (FBIS-BR). J Bras Psiquiatr 54: 206-214.

27. Kate N, Grover S, Kulhara P, Nehra R (2013) Relationship of caregive burden with coping strategies, social support, psychological morbidity, and quality of life in the caregivers of schizophrenia. Asian Psychiatr 6: 380-388.

28. Tabaquim ML, Marquesini MA (2013) Study of the stress of parentes of patients with cleft palate in surgical process. Estudos de Psicologia 30: $517-$ 524.

29. Sparrow D, Cicchetti DB (2005) VINELAND-II - Escalas de Comportamento Adaptativo de Vineland. $2^{\mathrm{a}}$ edição, Americana.

30. Fonseca V (2008) Desenvolvimento psicomotor e aprendizagem.
31. Camargos AC, Lacerda TT, Viana SO, Pinto LR, Fonseca ML (2009) Avaliação da sobrecarga do cuidador de crianças com paralisia cerebral através da escala Burden Interview. Rev Bras Saúde Mater Infant 9.

32. Bee H, Boyd D (2011) A criança em desenvolvimento. 12ª edição, Humanas.

33. Jacob MF, Tabaquim ML (2014) Atenção e linguagem em crianças com fissura labiopalatina. Rev Saúde e Desenvolvimento Humano 2: 15-27.

34. Lamônica DA, Vitto LP, Garcia FC, Campos LC (2005) Avaliação do processo receptivo: investigação do desenvolvimento semântico em indivíduos com Síndrome de Down. Rev Bras Educ Espec 11: 81-96.

35. Joaquim RM, Tabaquim ML, do Valle TG (2014) Estratégias de enfrentamento e níveis de ansiedade de mulheres em tratamento psicológico. Arch Health Invest 3: 39-57.

\section{Acknowledgements}

We would like to thank Mr. Giovani Merighi Tabaquim for the technical work of the Portuguese translation to English language. 